\title{
Q.
QNEEN'S
UNIVERSITY
BELFAST
}

\section{The Year's Work in Stylistics 2017}

Lugea, J. (2018). The Year's Work in Stylistics 2017. Language and Literature, 27(4), 329-352.

https://doi.org/10.1177/0963947018799777

\section{Published in:}

Language and Literature

Document Version:

Peer reviewed version

Queen's University Belfast - Research Portal:

Link to publication record in Queen's University Belfast Research Portal

Publisher rights

(c) 2017 The Author

This work is made available online in accordance with the publisher's policies. Please refer to any applicable terms of use of the publisher.

\section{General rights}

Copyright for the publications made accessible via the Queen's University Belfast Research Portal is retained by the author(s) and / or other copyright owners and it is a condition of accessing these publications that users recognise and abide by the legal requirements associated with these rights.

Take down policy

The Research Portal is Queen's institutional repository that provides access to Queen's research output. Every effort has been made to ensure that content in the Research Portal does not infringe any person's rights, or applicable UK laws. If you discover content in the Research Portal that you believe breaches copyright or violates any law, please contact openaccess@qub.ac.uk. 
"It is not the literal past, the 'facts' of history, that shape us, but images of the past embodied in language [...] We must never cease renewing those images; because once we do, we fossilize."

Translations, by Brian Friel (1981: 66)

\section{Stylistics: then, now, and everywhen}

The year 2017 was one of deictic exploration for stylistics, whereby through exploring the spatio-temporal contours of our discipline we reach a better understand of where we are now. My point is demonstrated in this section, where I cover retrospectives and reprints of past work in stylistics (Burke, 2017; Fowler, 2017), as well as a new textbook for the instruction of future stylisticians (Gibbons and Whiteley, 2017) and a volume which sketches out the current 'landscape' of stylistics (Douthwaite et al., 2017). In the subsequent sections, I consider this landscape under arbitrary headings for the purposes of toponymy which, as Brian Friel's play Translations reminds us, can be political, but is nonetheless necessary for finding one's way around a field. As always, articles published in this journal are not included in the list of references to avoid self-citation predicaments, but readers are signposted to the relevant issue of Language and Literature where they are encouraged to read more.

I knew I had my work cut out for me this year when the weighty fourvolume Stylistics (Burke, 2017) landed on my desk. A major reference work reprinting key publications spanning almost sixty years in four hardback volumes, it is part of Routledge's 'Critical Concepts in Linguistics' series. As such, it joins the ranks of other sub-disciplines of linguistics featured in the series, including Pragmatics (Kasher, 1998), Critical Discourse Analysis (Toolan, 2002), and Sociolinguistics (Coopland and Jaworski, 2009). Last year I referred to the publication of several handbooks of stylistics in recent years (Stockwell and Whiteley, 2014; Burke, 2014; Sotirova, 2015) as an indication of disciplinary health; if those handbooks were indicative of our field's strength, then Burke's compilation of this major reference work provides further evidence of this. The first tome begins with Jakobson's (1960) 'Closing statement: linguistics and poetics', unfortunately named as it is often considered an opening move towards our contemporary understanding of the role of poetic language in relation to language at large. The fourth and final volume ends with chapters that, like the headings in this article, relate to ongoing and contemporary concerns. As with the series' other titles, Stylistico organises the contributions to demonstrate the historical and thematic development of the field. The four volumes are: i) Theory, Method and History; ii) Pragmatics, Discourse and Narrative; iii) The Practical Value of Stylistic Analysis; and, iv) The Multidisciplinarity of Stylistics.

Although the chapters are not ordered in strict accordance with their year of first publication, Burke's well-considered structure captures temporal and scholarly developments in stylistic research over the decades. Volume I 'Theory, Method and History' reprints Halliday's (1971/2017) seminal analysis 
of Lok's mind style in The Inberitors, which truly demonstrated how Systemic Functional Linguistics can explain the link between lexico-grammatical choices and literary effects. This shining example of early stylistic enquiry is followed by Fish's infamous 'quarrel with the stylisticians' (1971/2017: 81) and any claims laid to the method's affordance of objective interpretation, before Toolan's rejoinder to Fish's 'characteristically bald assertion[s]' (1990/2017: 106) which deals with Fish's criticisms in sensitive and serious detail, both providing issues for debate around the object and method of stylistic enquiry that are still relevant today. The first volume also offers several chapters which explore the history of the field in terms of its relation with classical rhetoric and poetics (Hamilton, 2014/2017, Cockcroft, 2004/2017, Fahnestock, 2005/2017, Verdonk, 1999/2017), as well as chapters which attempt to define 'style' (Verdonk, 2006/2017) and the contents and purpose of the 'stylistic tool-kit' (Wales, 2014/2017; see Dawson [2017] extend this metaphor to the narratological 'toolbox').

Volume II 'Pragmatics, Discourse and Narrative' brings together greaterand lesser-known work which analyses stylistic features in relation to their communicative effects, such as viewpoint construction in fiction (Simpson, 2010/2017, Short, 1999/2017) and in drama (McIntyre, 2004/2017), and the pragmatics of dramatic dialogue, (Culpeper 1998/2017). We learn how stylistics intersects with narratology (Shen, 2005/2017), and can characterise the degree, extent and nature of the involvement of editors (Arai, 2007/2017) characters (Bockting, 1994/2017) and narrators (Ikeo, 2007/2017) in narrative prose. In Volume III, the practical value of stylistics is extended beyond its analytical toolkit towards its use in translation (Boase-Beier, 2014/2017) and in creative writing (Scott, 2012/2017), in Teaching English as a Foreign Language (Adamson, 1989/2017; Hall, 2012/2017) and in pedagogical stylistics more generally (Clark and Zyngier, 2003/2017; Zyngier and Fialho, 2010/2017; Carter, 1989/2017; McIntyre, 2012/2017; Zerkowitz, 2012/2017; Verdonk, 2013/2017). From what seems like quite a strong emphasis on pedagogical stylistics in Volume III, in addressing 'The Multidisciplinarity of Stylistics' Volume IV then includes the corpus, cognitive and multimodal concerns so prevalent in the field today and which were introduced in earlier volumes. Although some contemporary developments are not elaborated in detail in Stylistics, with Text-world Theory (Werth, 1994/2017; Semino, 1995/2017; Cruickshank and Lahey, 2010/2017; Gavins, 2012/2017) and reader-response research (Bray, 2007/2017; Emmott et al., 2007/2017; Stockwell, 2012/2017; Canning and Simpson, 2012/2017; Allington and Swann, 2009/2017) captured in sporadic chapters, the contributions are well-selected for how they both illustrate and advance research in these developing areas. This vast and ambitious collection is an indication of how far research in the field has come and will continue to be an incredibly valuable retrospective on the story of stylistics. 
We are given another window on stylistics' past through the republication of Fowler's (1966/2017) edited collection of Essays on Style and Language, as part of the Routledge Revivals series. The charm with reading this today is in the nascent ideas that we now take for granted. At the time of its first publication, 'viewing literary style through the eyes of a modern linguist' was a 'novelty' (Fowler, 1966/2017: vii). Cognisant of classical rhetoric as a precursor to their work, Fowler describes his endeavours as 'non-prescriptive Rhetoric' (1966/2017: viii) and Leech (1966/2017) demonstrates how literary language uses degrees of deviation to create rhetorical figures. Sinclair shows how to take a Larkin poem 'to pieces' and focuses on grammar rather than lexis because 'we have no proper description of English vocabulary patterns to use as a basis' (1996/2017: 68); of course, that same year he wrote about the Firthian concept of 'collocation' (1966) and he would later go on to develop the first corpus-based dictionary, COBUILD. The effect of reviving this previously out-of-print title is to remind us how innovative linguistic criticism was and how transcendent its basic tenets are (see, for example, GómezJiménez [2017] and McIntyre and Jeffries [2017] on poetic foregrounding; coincidentally, both examine the work of E.E. Cummings).

From a collection of key past works in stylistics to a textbook instructing future scholars how to do stylistics, Gibbons and Whiteley's (2017) Contemporary Stylistics: Language, Cognition, Interpretation offers teachers and students a comprehensive overview of the field today, continuing the contemporary focus with reference to many modern literary texts throughout. Parts I, II and III introduce stylistics and provide extensive coverage of the levels of language and discourse at which style can analysed. Part IV 'Text as Cognition' provides students with a much-needed accessible account of cognitive stylistics, including deixis, schemas, prototypicality and cognitive grammar. Parts V-VII consist of an extended consideration of 'reading' which encompasses cognition, emotion, reader response methods and, curiously, multimodal and corpus analysis. The consideration of the latter two topics as 'reading' can be explained by the authors' emphasis on the readerly experience, that of the real reader and the analyst. Students of stylistics will no doubt find this conflating focus one that helps them explain and analyse their own reading experiences, empowering them to take the subject further. The twenty-three chapters may prove too numerous for the average semester-length course but, as the chapters easily stand alone, they can be selected to create a coherent course; each includes helpful tables and diagrams of taxonomies and concludes with suggestions for activities and further reading.

Like Gibbons and Whiteley (2017), the editors of The Stylistics of Landscapes, the Landscapes of Stylistics (Douthwaite et al., 2017) stress the centrality of cognition in interpreting literary language and, therefore, its centrality to stylistics, no longer simply a 'branch' of the field. In the volume's introduction, they also point out that even prior to the 'cognitive revolution', 
stylistics' use of models from pragmatics implicitly entailed an understanding that intentionality, or participants' minds, were central to discourse and its processing. The literary landscapes analysed in the book (and beyond, landscapes being the theme of the 2010 PALA conference in Genoa and the subject of a dedicated Special Interest Group, LAND-SIG) evoke not only literal, physical scenes but also metaphorical portraits of people, places and society' (Douthwaite et al., 2017: 2). Crucially, these landscapes are not simply described, but filtered through a subjective experience and are therefore personal, social and ideological. In this way, the editors of this collection cultivate a kind of stylistics characterised by Fowler (1986), who stressed that literature is social discourse and stylistics performs social criticism. The first two chapters (Short 2017; Wales 2017) deal with different features of Dickens' travelogue of Genoa, revealing how he creates a cacophonic, impressionistic representation of the city. Their analyses bring to life for me a city I will always recall fondly for providing the cityscape, soundtrack and sensations of my first PALA conference. Wales's and Short's chapters are based on papers presented in Genoa and they cross-reference one another's work, yet independently arrive at similar interpretations of Dickens' style, lending weight to the strength of their claims; this typifies the rigorous, collaborative and accessible nature of work in our field, another 'impression' I took from that conference that this volume reactivates. Because of these embodied, social and academic memories, in reading these two chapters I was struck by the powerful links between text, context and personal and social cognition that the editors consider under the umbrella term 'landscape'. Throughout the remaining chapters, the contributions are selected for their social concerns, as well as analysis of literature that is non-canonical or in languages other than English. While ecostylistics may be a fledgling branch of the field, this volume contributes greatly to the landscape of stylistics as a whole.

\section{Cognition}

The 'cognitive revolution' mentioned above is one that continues to evolve as the study of language and literature interact with the cognitive sciences in various ways. While cognitive stylistics/poetics continues to adopt theories and methods to shed light on fiction and literary reading, the burgeoning field of Cognitive Literary Science (CLSci) emphasises the interdisciplinary exchange between literary study and the cognitive sciences; in other words, it also addresses the question as to what literature and literary reading can teach us about cognition. Coined by Burke and Troscianko (2013) in their introduction to a special issue of the Journal of Literary Semantico, CLSci is further developed in their new edited volume (Burke and Troscianko, 2017). The volume's three parts demonstrate how the two fields interact with one another: Part I deals with 'Literature through a Cognitive Lens', Part II studies 'Cognition through a Literary Lens' and Part III examines 'Literature and Cognition in Cognitive 
Science'. Their introduction responds to the contributions collectively, using them to describe CLSci concerns, which include the 'Big Six cognitive-literary topics-embodiment, emotion, immersion, mental imagery, simulation and social cognition' (2017: 5). In addition, they identify emerging strands of research, such as the significance of cognitive 'feedback' in reading literature (the idea that 'reading supplements my feelings rather than creates my feelings', as described by a survey respondent [Troscianko, 2017: 169]), which can have important implications for memory, emotion and experience in literary reading. The insights that literary scholarship can provide on cognition are usually less explored and CLSci attempts to redress that in Part II where, for example, an analysis of Miller's play After the Fall leads to a re-understanding of psychoanalytical accounts of transference (Hogan, 2017). As the editors note, work in CLSci does not necessarily draw on linguistics but, when it does, cognitive stylistics in particular offers a means to cross the boundaries between literature, language and cognition.

The link between the two latter subjects is elucidated in The Cambridge Handbook of Cognitive Linguistics, expertly introduced and edited by Dancygier (2017a), who also authors an individual chapter on the role of cognitive linguistics in studying textual meaning in literary and non-literary texts (Dancygier, 2017b). The division of the forty-one chapters into six distinct parts lends clarity to the structure. The contributions in Part I deal with 'Language in Cognition and Culture', while Part II is dedicated to 'Language, Body and Multimodal Communication'. In the latter section, Vandelanotte (2017) discusses how viewpoint is intersubjectively and multimodally constructed in discourse (see also Dancygier and Vandelanotte, 2017, who elaborate on Discourse Viewpoint Space in relation to internet memes). Part III is dedicated to 'Aspects of Linguistic Analysis', with chapters loosely related to linguistic levels, within which the basic tenets of 'Cognitive grammar' (Langacker, 2017) and construction grammars (Hoffmann, 2017) are outlined. Perhaps most relevant for stylisticians is Part IV where the contributions deal with 'Conceptual Mappings', or meaning relations where 'cognitive linguistics treats the boundary between literalness and figuration as a matter of the patterns of use of complex knowledge structures, called frames or domains' (Sweetser, 2017: 379). While readers won't be surprised to find helpful and upto-date introductions to 'Conceptual blending theory' (Oakley and Pascual, 2017), 'Metonymy' (Littlemore, 2017) and 'Conceptual metaphor' (Sullivan, 2017), chapters such as Semino's (2017) 'Corpus linguistics and metaphor' really make this handbook contemporary and demonstrate Cognitive Linguistics' commitment to authentic data and empirical methods. Part V continues in this vein by detailing various methodologies in the field including the 'quantitative turn' (Janda, 2017) and computational (Boas, 2017; David, 2017) and corpus approaches (Gries, 2017). Finally, Part VI deals with 'Space and Time' in several chapters which explore various conceptualisations of and 
The Years Work in Stylistics 2017 Jane Lugea, Queen's University Belfast, UK approaches to these fundamental dimensions. This is an essential reference text which holds many gems for better understanding cognitive linguistics' intersections with stylistic concerns.

Developments in scholarly approaches to metaphor have had profound implications for stylisticians' analyses of this important linguistic trope. Since Lakoff and Johnson's (1980) seminal work on Conceptual Metaphor Theory (CMT), the pervasiveness and cognitive basis of metaphors have been widely accepted and further explored in everyday and fictional discourse. The year 2017 saw CMT applied and developed by scholars in, for example, Vogel's (2017) analysis of concreteness in the metaphors of the Swedish poet Tranströmer and Senkbeil's (Language and Literature 26:4, 2017) consideration of image schemas in horror texts across modes and cultures. Although still as pervasive as the metaphors it purports to describe, CMT was eventually superseded by Blending Theory (Fauconnier and Turner, 2002) which proposes the fusion of source and target domains and a resultant emergent structure (see Schubert 2017 on blending as a tool in the characterisation of antiheroes in contemporary TV drama). However, the editors of a special issue of Poeticd Today (Goodblatt and Glickson, 2017a) revive a predecessor to Blending Theory, Black's (1962; 1993) earlier Interaction Theory, which explores the 'iterative process of metaphor comprehension' (Goodblatt and Glickson, 2017b: 4). Building on Black's Interaction Theory, the articles in this issue explore bidirectionality in metaphor, which entails 'a continued potentiality for - and tension among - possible readings', unlike Blending Theory's 'complete fusion of the two domains' (Goodblatt and Glicksohn, 2017: 7). In one of the contributions, Freeman describes how the editors' call to rethink metaphorical mappings in this way has led her to conclude that 'not only is metaphorical bidirectionality possible, it explains how the arts enable us to iconically connect with the world through our embodied cognition, $[\ldots]$ as participatory sharers of that world' (2017a: 61). This bodes well for an exciting, renewed (bi!)direction in metaphor studies and conceptual mapping more generally.

Within the field of cognitive linguistics, Langacker's (1987; 1991; 2017) Cognitive Grammar (CG) is often touted to be more applicable to short texts because it initially focused on clause-level constructions, yet recently it has been used to analyse stretches of narrative (e.g. Harrison et al., 2014; Harrison, 2017a). In Cognitive Grammar in Contemporary Fiction (Harrison, 2017b) we have, for the first time, an extensive study of how CG can be used to account for the cognitive effects of stylistic choices in a range of contemporary prose. After an instructive overview of CG. Harrison analyses a different prose text in each chapter, employing CG concepts to explain, for example, the 'sense of momentum' (2017b: 46) in an extract from Enduring Love, to track character roles in The New York Trilogy, and to elaborate interrelated fictional worlds in Coraline. In the latter two chapters, she uses reader response data to support 
her analyses and, moreover, to demonstrate that CG not only describes authorial choices in the text but also the attentional effects they have on readers i.e. both sides of the communicative dyad. With CG being adopted increasingly in stylistic research, this is an important monograph in a growing field and is demonstrative of the literary insights the model can provide when in the right hands.

\section{Rhetoric and Poetics}

Although cognitive approaches to stylistics are characteristic of much research in recent decades, rhetoric is the discipline's forerunner and, in its traditional and contemporary forms, still has much to offer in the analysis of figurative and persuasive language. In What is Rhetoric? (2017), Meyer defines rhetorical discourse as the negotiation of distance between individuals, the speaker (ethos) and the audience (pathos), on a given question (logos)' (2017: 9). Central to his understanding of rhetoric is the equal value given to ethos, logos and pathos, as well as 'the question view of language and reason' whereby rhetorical discourse is underpinned by the need to address a question, through expression, debate or representation. The notion of the question is used by Meyer to unify two strands of rhetoric often dealt with separately in academic scholarship: argumentation and stricto sensu (figurative language). Stylisticians will get most value from the chapters dedicated to figurative language, the rhetoric of literature and the arts, yet Meyer's overall gestalt understanding of rhetoric chimes with stylistics' dual concern with literary and non-literary language, as well as our discourse approach to texts, where participants and contexts are intrinsic to their meaning.

More in the tradition of poetics, Dolven (2017) makes a book out of precisely 396 remarks on the subject of 'style', ranging from a single sentence to a few paragraphs in length. Some are bizarre and could be discussed in terms of their own foregrounding, such as entry number 8, 'Everything has a style. Take a shard of pottery, and place it in the history of Athens; take a safety pin, and stick it in your ear' (2017:5). That the author is a poet comes as no surprise and his creative practice no doubt informs the observations, which are organised into thematic chapters. Particularly interesting are entries on the relationship between style and form, such as 'Form is vertical. Style is horizontal' (2017: 88) which is reminiscent of the Saussurean distinction between the syntagmatic and paradigmatic, or 'Form is singular. Style is plural' (2017: 89), which may cryptically refer to the fact that style makes use of repeated forms. Dolven does not engage with linguistic approaches to style, instead taking poetics and aesthetics as his starting point, and grounding some of his observations with reference to the work of two historically distinct poets, $16^{\text {th }}$ century Englishman Sir Thomas Wyatt and midcentury American poet Frank O'Hara. It is a strange collection of remarks on a subject that stylisticians deal with very differently, but there are some nuggets, interesting 
for their alienating effects on a subject we 'know' so well and in a style so different from the usual academic prose.

In a more familiar academic style, Camper (2017) outlines a rhetorical method for understanding how people disagree over textual meaning and how they advance arguments in the negotiation of textual meaning. Drawing on an ancient theory of interpretative stases, Camper proposes that there are six stases that can be at the centre of an interpretative dispute, including i) textual ambiguity, ii) terminological definitions, iii) possible applications or inferences, iv) a text's jurisdiction or legitimacy, as well as v) conflicting passages or vi) a conflict between wording and authorial intention. These stases are each dealt with in individual chapters, with reference to examples of interpretative disputes from law, history, politics, religion and literary criticism. In a closing chapter, Camper outlines the logical order of these stases in an interpretative argument and considers the wider implications for communities in conflict over textual interpretation. The book is an example of how hermeneutics and rhetoric can offer a framework for understanding a specific kind of conflict. As part of John Benjamins's 'Argumentation in Context' series, an edited volume was published bringing together research on discourses in which text, image and other semiotic modes are combined to create meaning in argumentative contexts (Tseronis and Forceville, 2017). These contexts include film trailers (Wildfeuer and Pollaroli, 2017), editorial cartoons (van den Hoven and Schilperoord, 2017; Groarke, 2017), press photography (Kjeldsen, 2017), and political advertising and discourse (Poggi, 2017). The editors and their contributors address fundamental issues as to how arguments can be evaluated in non-verbal modes and how 'mode-specific theories' (Van den Hoven and Yang, 2012) on argumentation can be advanced.

Noting the longstanding preoccupation with metaphor in literature (see Section 2), Riddle Harding addresses the imbalance in a monograph dedicated to other kinds of figurative language: Similes, Puns and Counterfactuals in Literary Narrative (2017), part of the 'Routledge Studies in Rhetoric and Stylistics' series. The three phenomena are dealt with in turn by means of a chapter conceptualising each figurative form then a subsequent chapter demonstrating its function in literary narrative, using short stories as illustrative data. Similes are characterised by their 'intentionality' and 'visibility' and resultant implications for discourse roles, characterisation and voice (see also Lou [2017] on the use of similes in multimodal internet memes). Puns are 'based on the unit of the word, rely on a doubling of contextual relevance, and create a humorous, provocative or poignant effect' (2017: 64). Like similes and puns, Riddle Harding argues, counterfactuals are figures of speech that depend on 'duality' for achieving rhetorical effects and support conceptual comparisons. The monograph is very clearly structured and the explanations clear and illustrated well through the analysis chapters, concluding with suggestions for pursuing these rhetorical figures in discourse types other than narrative, from 
poetry to rap, thus demonstrating how rhetoric remains relevant for the analysis of contemporary forms.

\section{Narrative}

A longstanding central concern of stylistics, research in narrative continues with considerations of the complex statuses and interrelations of authors, narrators, characters and readers and their roles, voices and subjectivities. For example, in Character Focalization in Children's Novelo, Philpot (2017) takes a systemic-functional approach to understanding how ten novels use child characters as focalizers for their narratives. With careful attention to lexicogrammatical features and description of focalizing clauses, Philpot tracks how bearing, seeing, emoting and thinking are represented across the texts. In identifying patterns that continue, are reconfigured or augmented, he also tracks focalization at a discourse level, which is a key strength of the research. This monograph contributes a method for analysing narrative focalization at micro and macro levels, and in other genres of narrative. For those interested specifically in children's literature, novel-length focalization offers a way of understanding the child character's changing perceptions and personal development and Philpot concludes by considering the importance of this for young readers' awareness of self and others.

Two titles published in John Benjamins's 'Linguistic Approaches to Literature' series deal with literary narrative in very different ways. These are Rundquist (2017) and Hakemulder et al. (2017). Rundquist (2017) elaborates on the inexhaustible topic of Free Indirect Style (FIS), as used in the representation of consciousness. In contrast with those who understand FIS as a means of discourse presentation (e.g. Genette, 1972; Fludernik, 1993), Rundquist instead focuses on its capacity to represent the preverbal subjectivity of literary characters, as well as the dual subjectivity of both the character and the narrator. Although recognition of the 'dual voice' in FIS is not new (Pascal, 1997; Sotirova, 2013), there is increasing awareness of narratorial subjectivity in FIS (Gunn, 2017) or even the potential unreliability of the third person narrator in FIS, which Murphy and Walsh (2017) demonstrate is a key feature of Katherine Mansfield's short stories. Over the course of Rundquist's clearly-structured monograph, his argument is developed through stylistic analyses of extracts from Modernist fiction, including Virginia Woolf's To the Lighthouse, D. H. Lawrence's The Rainbow and James Joyce's Ulysdes. As well as advancing a conceptualisation of FIS as a mode for representing consciousness of character and narrator, the analyses and resultant interpretations are related to literary-critical understandings of the texts; noting the recent trend for incorporating real readers' responses into stylistic enquiry (Hakemulder and Van Peer, 2016; Canning and Whiteley, 2017), Rundquist engages with the readings of literary critics, which he 
considers to constitute equally valid reader-response data. The result is a lucid literary stylistic account of FIS in these texts, which through their complex uses of the strategy, provide rich data to elucidate how fictional language represents the non-linguistic consciousness of characters (and narrators) through FIS.

The same series includes an edited volume dedicated to Narrative Absorption (Hakemulder et al., 2017), that feeling of being lost in a story which scholars from various disparate disciplines have tried to pin down. Indeed, the opening chapter (Bilandzic and Busselle, 2017) addresses the myriad of scholarly terms to describe 'absorption-like states' and draws out useful conceptual distinctions, laying helpful groundwork for subsequent chapters. The second chapter suggests that previous absorption research has neglected the role that formal and stylistic features play in creating the effect and offers a taxonomy of absorption-like states, as well as a theoretical framework for understanding 'narrative aesthetic absorption' (Kuijpers et al., 2017). Although the volume is clearly organised in three parts, 'conceptualisations', 'empirical studies on' and 'outcomes of' narrative absorption, many of the contributions provide empirical evidence accounting for real readers' absorptive experiences of narrative, reflecting the aforementioned trend towards investigating the experiences of real readers. Jacobs and Lüdtke (2017) consider different kinds of immersion in narrative and poetic worlds (e.g. concentration, attention, suspense, empathy) from the perspective of 'neurocognitive poetics', based on Jacobs' (2015) model which sees immersive and aesthetic processes as rival forces in literary reading (see Kuzmičová et al. in Language and Literature 26:2, 2017, who provide additional evidence for this model, at least in relation to the unempathetic effects of foregrounding). As well as weighing up methodological issues in inducing and measuring immersion, Jacobs and Lüdtke report on the results of empirical studies which demonstrate considerable variation in readers' 'styles of moving into literary worlds' (2017: 87). This volume is an important collection of fascinating interdisciplinary research on narratives' capacity to absorb, transport and effect readers in profound ways. Not limited to literary narrative, other contributions deal with absorption in film narratives (Kessler, 2017; Tan et al., 2017) and health narratives (de Graaf and van Leeuwen, 2017), and even audiences' identification with television characters (Cohen and Tal-Or, 2017).

Research continues on the uses of narratives in non-literary interactions. A special issue of Style dedicated to everyday narratives contains six articles which explore how people tell stories across a wide range of contexts: medicine and therapy, social work, oral history, new media, with an emphasis on the expression of 'narratives selves' in these differently mediated environments (Hatavara et al., 2017). In Page's (2017) monograph, Narratives Online: Shared Stories on Social Media, she considers the co-creation of stories facilitated by digital media platforms such as Wikipedia, Facebook, YouTube and Twitter. 
The Years Work in Stylistics 2017 Jane Lugea, Queen's University Belfast, UK Page notes that collective storytelling has received limited narratological attention, but that seems to be changing with her own detailed consideration of shared stories in social media contexts, Fludernik's (2017) analysis of collectivity in literary narrative and Marlar Lwin's study of collective oral storytelling (Language and Literature 26:1, 2017). Consideration of participatory media opens the doors on a narratology which is not just reader-oriented but considers the complex roles involved in shared narratives. Page does so through what she terms 'mediated narrative analysis' which draws on Critical Discourse Analysis, interactional sociolinguistics, social semiotics and narrative analysis to provide a toolkit for analysing shared stories. Her method triangulates qualitative discourse analysis with a corpus approach using AntConc to explore concordances and keywords in the data, which includes the Wikipedia entry on Meredith Kercher's murder and the YouTube coverage of Oscar Pistorius from his days as an athlete to being prosecuted for the murder of his wife. As these examples suggest, 'shared stories' are conceived of in a broad, dissolute manner, yet this approach allows the researcher to contribute to understandings of narrative as co-created, interactive, intertextual, multimodal and as being elaborated over time and to different patterns of linearity.

Based on Page's earlier (2010) observation that the verbal mode is only one of many involved in storytelling, Gregoriou (2017) explores the tendency and processes by which crime fiction is adapted and translated into other modes, contexts and/or languages, which she terms the 'crime fiction migration effect'. This phenomenon is illustrated through, amongst other case studies, the novelization and translation of Danish television series The Killing, the dramatisation of the novel Curious Incident of the Dog in the Night-time and the translation of Greek crime novel Late-Night Newd into English. Drawing on a range of cognitive poetic models, including mind style, conceptual metaphor theory, and Emmott's (1997) contextual frame theory, Gregoriou takes each textual 'migration' in turn, elucidating the transference of semiotic forms and meanings involved in each adaptation (for several articles on the subject of adaptation, see English Text Construction [Callens 2017]). Gregoriou's research has significance for the growing interest in 'transmedial narratology', to which a special issue of Narrative was dedicated last year. Therein, the guest editors observed that we should not only focus on 'specific narrative affordances and limitations of individual media but also on the transmedial dimension of narrative structures and strategies as they are realized across media' (Kuhn and Thon, 2017: 254, authors' emphasis). In that special issue of Narrative, Gibbons (2017) addresses the fact that readerly involvement in creating transmedial narrative worlds has been overlooked and studies reader responses, drawn mostly from Twitter, towards a printed multimodal novel. Her analysis uses Text World Theory to describe the textual structure of the novel and then demonstrates how the narrative is constructed beyond the confines of the page 
through marginalia, external links and readerly participation in this network of media to construct the storyworld. Given the emergence of 'participatory culture' (Jenkins, 2006), it stands to reason that narratology should be taking turns towards collective narratives and readerly involvement in their construction across media.

Of course some of these themes have long been studied in relation to the translation of narrative, where stylistic concerns have been addressed to different extents. In XU Yun's (2017) Translation of Autobiograpby, she uses the complexity of voices and viewpoints in autobiographies and their translations to explore a wide gamut of stylistic concerns: from foregrounding to mind style, speech and thought presentation, irony, empathy and narratorial reliability. Although the texts studied are drawn from the specific Singaporean linguistic context, the issues they raise and the range of stylistic models used to understand them means this monograph holds a broad appeal for stylisticians and, more generally, those wishing to understand autobiography as a genre and the mechanisms of its translation. XU Yun demonstrates how the mediating consciousness of a translator can affect the factual, attitudinal and ideological viewpoint in the narratives. These findings are echoed in Yu's analysis of the canonical Chinese translation of Huckleberry Finn, where the social structures of the text are altered as a result of the choices made in dialect translation (Language and Literature, 26:1, 2017). As much of the research summarised here demonstrates, analysing the 'migration' of narratives from one mode or medium to another can tell us more about the narrative itself, it structure, properties and functions.

\section{Corpora}

I have mentioned recent publications which employ corpus methods already, but such is the extent of work in corpus stylistics that it merits a dedicated section. Our readers' interest may have piqued at news of the free, open source Corpus of the Canon of Western Literature (CCWL), as publicised in Green's article (Language and Literature, 26:4, 2017). The corpus is based on Harold Bloom's (1994) characterisation of the western literary canon (which is inevitably biased towards Anglophone male authors) and contains 73 million words in literary texts drawn from Project Gutenberg. Green demonstrates how, when compared to the British National Corpus, many of the top-ranking keywords in CCWL are male pronouns, illustrating the centrality of the male view in canonical literature. Green describes how the corpus can be used for, in addition to corpus stylistics, 'culturanomics'; that is, the tracking of cultural trends and social psychology through linguistic big data. In another article in this journal, Eberhardt (Language and Literature, 26:3, 2017) uses corpus stylistic methods to demonstrate the asymmetrical use of speech presentation in the two side-kick characters in Harry Potter, Hermione and Ron, which she relates to social gender binaries at large. 
Although it shares part of its name with our field, Computational Stylistics does not necessarily entail the application of linguistic models for the analysis of texts; rather, the focus is on using computational and statistical methods to identify patterns in literary texts, considering their implications for literary authorship or criticism. Craig and Greatley-Hirsch (2017) do just that with a corpus of early modern plays, which have undergone considerable research with regards their authorship, but had not otherwise been thoroughly examined using computational methods. The authors do not make their research questions clear and the reader is left to assume that the research is data-driven, rather than based on questions arising from literary criticism or insights (Mahlberg 2007 makes this distinction in departure points for corpus studies of literary texts). Locating their research as a legacy of Burrows' work in early Computational Stylistics, they provide an extremely elucidating chapter on methods, which explains statistical procedures such as Principal Components Analysis, Delta (Burrows, 2002) and t-tests, in an accessible manner. In subsequent chapters they apply these methods to the data, leading to convincing conclusions about the differences between verse and prose, pre1642 and Restoration drama, characters, the use of props, and culturalhistorical changes over the early modern period.

As well as tracking stylistic differences across characters, texts, authors and time, corpus methods are useful for identifying style changes as a result of translation, which continues into 2017 thanks to the work of Mastropierro (2017) and Mastropierro and Mahlberg (2017). As part of Bloomsbury's 'Research in Corpus and Discourse' series, Mastropierro's (2017) monograph uses corpus methods to analyse four Italian translations of Joseph Conrad's Heart of Darkness, which provides fascinating data in its representation of Africa, race, and colonialism. Unlike Craig and Greatley-Hirsch (2017), Mastropierro devises his research questions based on these themes and their discussion in literary criticism, rather than looking to the data's statistics, based on the idea that a 'frequency-based selection can dismiss low-frequency items that can nevertheless play an important role in the process of theme construction' (2017: 41). Despite this divergence in approach to corpus research, Mastropierro also adopts PCA as a method of dealing with multiple observations about multiple variables, but in his case it serves to discern levels of similarities across the translated texts. As outlined above, unlike computational stylistics, corpus stylistics is usually supported with qualitative textual analysis and Mastropierro supports his corpus keyword analysis with Mahlberg and McIntyre's (2011) model of signal keywords for constructing the fictional world and its themes. Mastropierro's consideration of cohesion in Heart of Darkness is extended in his article with Mahlberg (Maestropierro and Mahlberg, 2017), where they use keywords to explore cohesive networks in an Italian translation of another novella At the Mountains of Madness. Cohesion and its translation has long been a subject of translation studies research (e.g. Blum- 
Kulka 1986; Baker 2011), so it is exciting to see corpus stylistics providing tools for its analysis.

Keywords continue to prove useful as a way in to literary texts and their translations (although see Vincent and Clarke in Language and Literature 26:3, 2017, who adopt a 'simple maths' method of identifying keyness, as opposed to log likelihood). In addition, keywords are also the way in to understanding the ideology espoused during the Blair years in British politics for Jeffries and Walker (2017). In order to understand the keywords during the decade of his governance, they create a corpus of almost 15 million words comprised of broadsheet news articles on politics and current affairs and compare them with a reference corpus. Unlike most reference corpora this one does not represent a general norm, but the six years of similar press reporting preceding Blair's first election win, so as to be able to chart the differences against a common background. Like Mastropierro (2017), they also emphasise that 'statistical significance does not necessarily equate to interpretative equivalence, or in our case sociopolitical significance' (Jeffries and Walker, 2017: 28) and provide clear criterion for the selection of six significant keywords, choice, global, reform, respect, spin and terror. These keywords then form the basis of each subsequent chapter, wherein their concordances are further analysed in order to better understand their use and meaning. They conclude that when a word become politically key, its everyday sense gives way to a specialised sense, which behaves in particular ways in terms of derivation and syntax. The authors note the unconscious and, consequently, unquestionable way this happens. The corpus work summarised in this chapter indicates how keyword analysis is a particularly useful tool for stylisticians to explore our corpora of literary or rhetorical texts (which are often smaller than corpora used by corpus linguists in general), as it can indicate concepts that merit further qualitative analysis.

\section{Media and Multimodality}

In the research discussed so far we have touched on studies of non-literary texts, including audiovisual drama (Gregoriou, 2017) and narratives online (Page, 2017) and in various other contexts (Hatavara et al., 2017). In this section, I summarise work that explicitly deals with multimodal and media discourse in ways that uphold the three cornerstones of stylistics: replicability, retrievability and rigour (Simpson, 2014).

Recognising that it is by no means obvious just which methods, which disciplines, which frameworks can help' in the systematic, holistic study of multimodal artefacts or performances, Bateman et al. (2017:9) have released an incredibly engaging and instructive textbook on the subject. In Part I, the first four chapters introduce the various modes and senses through which multimodal texts can operate, considering semiotics, discourse situations, text and genre; all familiar territory. However, the editors also refer to highly relevant but overlooked research in other fields, such as Human Computer 
Interaction. Part II outlines methodological design and methods, such as the use of eye-tracking technology and corpora. Interestingly, Bateman et al. suggest that multimodal researchers coming from different semiotic backgrounds should not attempt to 'speak the same language' (as Kress and Van Leewen [2006] advise), but instead should learn 'to speak each other's language[s]', which would involve triangulating results from studies of different modes, rather than mapping them onto one another (Bateman et al., 2017: 232). Finally, Part III consists of nine chapters exemplifying different 'use cases', with sample analyses of performances, graphic design, comics, film, social media and computer games. What a pity the book is not available in hardback, as I can imagine a student or tutor's paperback copy would be wellthumbed by the end of the exciting module this textbook could inspire.

An incredibly rich new book from Bednarek and Caple is about how news organisations "sell" the news to us as news through verbal and visual resources' (2017: 3, emphasis in original), and they elucidate this through Discursive News Values Analysis (DNVA). However, the research also employs a strong combination of approaches, which elsewhere the authors label 'Corpus-Assisted Multimodal Discourse Analysis' (CAMDA) (2014: 151), the theories and methods of which are carefully explained in this book, and could be employed beyond the analysis of newsworthiness. They recognise that while corpus approaches to discourse are commonplace, few also incorporate multimodality. In trying to make sense of the differing ways of doing CAMDA, they present a topology of ways of conducting analysis within and between texts and semiotics modes; herein, there are interesting intersections here with Bateman et al.'s (2017) textbook in attempting to describe methodological concerns in dealing with the vast array of semiotic modes within and across multimodal texts. Their introduction outlines the corpus tools used in subsequent chapters (including keywords, concordances and ProtAnt, a new software tool which uses keywords to identify prototypical texts in a corpus), as well as the concepts underscoring the multimodal analysis, mostly adapted from Kress and Van Leeuwen (2006). A very comprehensive literature review chapter leads to a clear definition of news values as limited to the newsworthiness of events as constructed through discourse, including the previously neglected visual mode. Echoing scholars in Critical Discourse Analysis (CDA), they suggest news values are themselves an ideological system which 'can work to reinforce other ideologies' (Bednarek and Caple, 2014: 45, emphasis in original). Their list of eleven news values is explained in detail, and discussed in terms of how they are represented linguistically and visually. Three analysis chapters then demonstrate how their DNVA model can be applied to three case studies, cyclists in the news, news on Facebook, and highly 'shared' news stories online. The strength of this book lies in the depth and detail of the primary and secondary research, which brings together corpus, discourse and multimodal approaches to provide a robust analytical 
framework that tells us much about news values but has significant wider applicability.

Because iconicity is inherently interdisciplinary it can be difficult to relate it to a sub-field of stylistics, but I include Dimensions of Iconicity (Zirker et al., 2017) here, as it deals with the phenomenon across dimensions, modes and media. The chapters are organised into those that consider iconicity along phonic, cognitive, performative and new dimensions. The two chapters that would be of particular interest to stylisticians take a cognitive approach to iconicity in poetry (Panagiodou, 2017; Freeman, 2017b), demonstrating how across the levels of language poetry can produce a semblance of another mode (another 'conceptual mapping [Sweetser, 2017]), leading Freeman to identify the generic metaphor, 'ART IS SEMBLANCE OF EXPERIENCED REALITY BY MAKING' (2017b: 114). Elsewhere in the volume, contributors explore iconicity between the antagonists and the rhetorical figures used to represent them in 'The Rape of Lucrece' (Zirker, 2017), in the neologisms found in Roald Dahl's The BFG (Shamina, 2017) and even provide a model of cross-modal iconicity (Elleström, 2017). In bringing together these different dimensions of iconicity, the latest title in John Benjamins' series dedicated to the topic is an important and exciting volume which demonstrates scholars continued interest in elucidating meaning across modes.

\section{Pragmatics}

Meaning in language and literature is most often explored through the prism of pragmatics, which underpins much research in stylistics and forms the primary focus of member of our association's Pragmatics Special Interest Group (PRAG-SIG). The latest in De Gruyter Mouton's 'Handbooks of Pragmatics' series will be of utmost interest to stylisticians; in introducing the Pragmatics of Fiction (Locher and Jucker, 2017), the editors acknowledge the significant use of pragmatics in stylistic research but emphasise the fact that pragmatics is centre stage in this volume, where fiction provides historical and communicatively complex data for pragmalinguistic research. Nonetheless, perhaps because this volume simply deals with the the communicative aspects of the language of fiction' (Locher and Jucker, 2017: 2), many of the contributions offer insights related to stylistics without being framed as stylistics per se, and thus offer excellent, accessible insights on highly relevant topics. For example, in a chapter which offers a comprehensive overview of research on 'voice' in fiction, CR Hoffman (2017) covers taxonomies of narrative perspective, viewpoint and speech and thought presentation, as well as mind style and characterisation and finally 'voice' as a cinematic practice; this chapter would provide students with a useful introduction to a range of related models. Elsewhere in the volume, Bednarek (2017) elucidates the role of dialogue in fiction, Busse (2017) outlines the intersections between stylistics 
and pragmatics, and Culpeper and Fernandez-Quintanilla (2017) explore fictional characterisation.

While two chapters in Pragmatics of Fiction deal with (im)politeness (Kizelbach, 2017; Dynel, 2017), the phenomenon is dealt with in vast detail in The Palgrave Handbook of Linguistic (Im)politeness (Culpeper et al., 2017). The editors stress the timeliness of a volume dedicated to the subject by referring to the marked increase in the use of the term '(im)politeness' in journal articles in the last decade and describe the subject as a 'jungle' for interested scholars. The structure of this weighty volume into three very general parts, 'Foundations', 'Developments' and '(Im) politeness in Specific Contexts', does not do much to clear the jungle. Nonetheless, scholars may find it useful to have such a comprehensive volume bringing together everything from the intersection of (im) politeness with power and solidarity (Spencer-Oatey and Žegarac, 2017), gender (Chalupnik et al., 2017) and its use in a wide range of contexts, the most relevant to stylisticians being fiction (McIntyre and Bousfield, 2017), politics (Tracy, 2017) and digital media (Graham and Hardaker, 2017). Chapters which summarise contemporary methods and experimental approaches (Holtgraves and Bonnefon, 2017; Jucker and Staley, 2017) place this volume at the cutting edge of the subject.

\section{Concluding Remarks}

Concluding this review of publications in stylistics and cognate fields in 2017 with Pragmatics forces one to probe the meaning of each contribution in relation to the discourse as a whole. I began this review article by reflecting on how recent publications revisit stylistics' past (Burke, 2017; Fowler, 1966/2017). It is important that present and future research in stylistics is carried out with a firm understanding of the field's past, our 'Common Ground' (Werth 1999) as it were. To a certain extent this past is shared by all of us, yet, as Douthwaite el al. (2017) observe, it is also socially and personally constructed according to lived, embodied experiences, which goes some way to explaining the heterogeneity of stylistic research. My own connection with the field is forged through my particular combination of academic interests, my enriching relationships with stylisticians and other scholars, and my first and ongoing experiences of annual PALA and other conferences, in familiar and not so familiar places. I write these concluding remarks 'fresh' from the 2018 PALA conference which took place in Birmingham (UK) and was, as ever, an intellectually stimulating and lively affair. Like the publications reviewed here, the sheer breadth of primary data (from literary, media and digital discourses, in English and other languages, and textual and other modes) as well as analytical approaches is staggering. Underpinning all of this work, however, is a shared drive to uncover how textual features relate to stylistic effects, a Common Ground that ensures stylistics' coherence and continuity, past, present and future. 
The Years Work in Stylistics 2017 Jane Lugea, Queen's University Belfast, UK

\section{References}

Adamson S (1989/2017) With double tongue: diglossia, stylistics and the teaching of English. In Burke M (ed) Stylistics. Vol. III The Practical Value of Stylistic Analysis. London and New York: Routledge, pp. 118133.

Allington D and Swann J (2009/2017) Researching literary reading as social practice. In Burke M (ed) Stylistics. Vol. III The Practical Value of Stylistic Analysis. London and New York: Routledge, pp. 150-61.

Arai K (2007/2017) Who controls the narrative? A stylistic comparison of the different versions of Raymond Carver's "So Much Water So Close to Home”. In Burke M (ed) Stylistics. Vol. II Pragmatics, Discourse and Narrative. London and New York: Routledge, pp. 30-50.

Baker M (2011) In Other Words: A Coursebook on Translation. London Routledge. 2 edition.

Bateman J, Wildfeuer J, and Hiippala T (eds) (2017) Multimodality: Foundations, Research and Analysis: A Problem-oriented Introduction. Berlin and Boston: De Gruyter.

Bednarek M (2017) The role of dialogue in fiction. In Locher M and Jucker A (eds) (2017) Pragmatics of Fiction. Berlin and Boston: De Gruyter, pp. 129-58.

Bednarek M and Caple H (2014) Why do news values matter? Towards a new methodological framework for analysing news discourse in Critical Discourse Analysis and beyond. Discourse and Society 25(2): 135-158.

Bednarek M and Caple H (2017) The Discourse of News Values: How Newd Organizations Create Newsworthiness. Oxford: Oxford University Press.

Black M (1962) Models and Metaphors: Studies in Language and Philosophy. Ithaca, NY: Cornell University Press.

Black M (1993) More about metaphor. In Ortony A (ed) Metaphor and Thought. Cambridge: Cambridge University Press, pp. 19-41.

Bloom H (1994) The Western Canon: The Books and School of the Ages. New York: Harcourt.

Blum-Kulka S (1986) Shifts of cohesion and coherence in translation'. In House $\mathrm{J}$ and Blum-Kulka S (eds) Interlingual and Intercultural Communication: Discourse and Cognition in Translation and Second Language Acquisition Studies. Tübingen: Gunter Narr Verlag, pp17-35. 
The Years Work in Stylistics 2017 Jane Lugea, Queen's University Belfast, UK

Boas HC (2017) Computational resources: FrameNet and construction. In B Dancygier (ed) The Cambridge Handbook of Cognitive Linguistics. Cambridge: Cambridge University Press, pp. 549-73.

Boase-Beier J (2014/2017) Translation and the representation of thought: the case of Herta Müller. In Burke M (ed) Stylistics. Vol. III The Practical Value of Stylistic Analysis. London and New York: Routledge, pp. 118133.

Bockting I (1994/2017) Mind Style as an interdisciplinary approach to characterisation in Faulkner. In Burke M (ed) Stylistics. Vol. II Pragmatics, Discourse and Narrative. London and New York: Routledge, pp. 115-33.

Bray J (2007/2017) The "dual voice" of free indirect discourse: A reading experiment'. In Burke M (ed) Stylistics. Vol. II Pragmatics, Discourse and Narrative. London and New York: Routledge, pp. 149-64.

Burke M (ed) (2017) Stylistics. London and New York: Routledge.

Burke M (2014) Rhetoric and poetics: The classical heritage of stylistics. In Burke M (ed) The Routledge Handbook of Stylistics. London and New York: Routledge, pp.11-30.

Burke M (ed) (2014) The Routledge Handbook of Stylistics. London and New York: Routledge.

Burke M and Troscianko ET (eds) (2013) Special Issue: Explorations in cognitive literary science. Journal of Literary Semantics 42(2).

Burke M and Troscianko ET (eds) (2017) Cognitive Literary Science: Dialogued between Literature and Cognition. Oxford: Oxford University Press.

Burrows J (2002) Delta: A measure of stylistic difference and a guide to likely authorship. Literary and Linguistic Computing 17(3): 267-86.

Busse B (2017) Pragmatics of style in fiction. In Locher M and Jucker A (eds) (2017) Pragmatics of Fiction. Berlin and Boston: De Gruyter, pp. 197 231 .

Camper M (2017) Arguing over Texts: The Rhetoric of Interpretation. Oxford: Oxford University Press.

Canning P and Whiteley S (eds) (2017) Special Issue: Stylistic approaches to reader response research. Language and Literature 26(2).

Canning P and Simpson P (2012/2017) Chicken and egg stylistics: From lexical semantics to conceptual integration theory. In Burke M (ed) Stylistics. Vol. III The Practical Value of Stylistic Analysis. London and New York: Routledge, pp. 181-99. 
The Years Work in Stylistics 2017 Jane Lugea, Queen's University Belfast, UK

Carter R (1989/2017) Directions in the teaching and study of English stylistics. In Burke M (ed) Stylistics. Vol. III The Practical Value of Stylistic Analysis. London and New York: Routledge, pp. 106-117.

Chalupnik M, Christie C and Mullany L (2017) (Im)politeness and gender. In Culpeper J, Haugh M and Kådår D (eds) The Palgrave Handbook of Linguistic (Im) politeness. Houndmills, Basingstoke: Palgrave Macmillan, pp. 517-37.

Clark U and Zyngier S (2003/2017) Towards a pedagogical stylistics. In Burke M (ed) Stylistics. Vol. III The Practical Value of Stylistic Analysis. London and New York: Routledge, pp. 45-57.

Cockcroft R (2004/2017) Putting Aristotle to the proof: Style, substance and the EPL group'. In Burke M (ed) Stylistics. Vol. I Theory, Method and History. London and New York: Routledge, pp. 355-76.

Cohen J and Tal-Or N (2017) Antecedents of identification: Character, text and audiences. In Hakemulder F, Kuijpers MM, Tan ES, Bålint K and Doicaru MM (eds) Narrative Absorption. Amsterdam and Philadelphia: John Benjamins, pp. 133-153.

Coopland N and Jaworski A (2009) (eds) Sociolinguistics. Critical Concepts in Linguistics series. London and New York: Routledge.

Craig H and Greatley-Hirsch B (2017) Style, Computers and Early Modern Drama: Beyond Authorship. Cambridge: Cambridge University Press.

Cruikshank T and Lahey E (2010/2017) 'Building the Stages of Drama: Towards a Text World Theory Account of Dramatic Play-texts'. In Burke M (ed) stylistics. Vol. II Pragmatics, Discourse and Narrative. London and New York: Routledge, pp. 301-23.

Culpeper J (1998/2017) (Im)politeness in dramatic dialogue. In Burke M (ed) Stylistics. Vol. II Pragmatics, Discourse and Narrative. London and New York: Routledge, pp. 273-85.

Culpeper J and Fernandez Quintanilla C (2017) Fictional characterisation. In Locher M and Jucker A (eds) (2017) Pragmatics of Fiction. Berlin and Boston: De Gruyter, pp. 93-128.

Culpeper J, Haugh M and Kådår D (eds) (2017) The Palgrave Handbook of Linguistic (Im) politeness. Houndmills, Basingstoke: Palgrave Macmillan.

Dancygier B (ed) (2017a) The Cambridge Handbook of Cognitive Linguistics. Cambridge: Cambridge University Press.

Dancygier B (2017b) Cognitive linguistics and the study of textual meaning. In Dancygier B (ed) The Cambridge Handbook of Cognitive Linguistico. Cambridge: Cambridge University Press, pp. 607-22. 
The Years Work in Stylistics 2017 Jane Lugea, Queen's University Belfast, UK

Dancygier B \& Vandelanotte L (2017) Internet memes as multimodal constructions. Cognitive Linguistics 28 (3):565-598.

David OA (2017) Computational approaches to metaphor. In Dancygier B (ed) The Cambridge Handbook of Cognitive Linguistics. Cambridge: Cambridge University Press, pp. 574-89.

Dawson P (2017) Delving into the narratological "toolbox": Concepts and categories in narrative theory. Style 51(2):228-245.

Dolven J (2017) Senses of Style: Poetry before Interpretation. Chicago and London: University of Chicago Press.

Douthwaite J, Virdis DF, Zurru E (eds) (2017) The Stylistics of Landscapes, the Landscapes of Stylistics. Linguistic Approaches to Literature series. Amsterdam and Philadelphia: John Benjamins.

Dynel M (2017) (Im)politeness and telecinematic discourse. In Locher M and Jucker A (eds) (2017) Pragmatics of Fiction. Berlin and Boston: De Gruyter, pp. 455-87.

Elleström L (2017) Bridging the gap between image and metaphor through cross-modal iconicity: An interdisciplinary model. In Zirker A, Bauer M, Fischer $\mathrm{O}$ and Ljungberg $\mathrm{C}$ (eds) Dimensions of Iconicity. Amsterdam and Philadelphia: John Benjamins, pp. 167-90.

Emmott C (1997) Narrative Comprehension: A Discourse Perspective. Oxford: Oxford University Press.

Emmott C, Sanford AJ and Dawydiak EJ (2007/2017) Stylistics meets cognitive science: Studying style in fiction and readers' attention from an interdisciplinary perpective. In Burke M (ed) Stylistics. Vol. IV The Multidisciplinarity of stylistics. London and New York: Routledge, pp. 96113.

Fahnestock J (2005/2017) Rhetorical stylistics. In Burke M (ed) Stylistics. Vol. I Theory, Method and History. London and New York: Routledge, pp. 377 92.

Fauconnier G and Turner M (2002) The Way We Think: Conceptual Blending and the Mind'd Hidden Complexities. New York: Basic Books.

Fish S (1973/2017) What is stylistics and why are they saying such terrible things about it?. In Burke M (ed) Stylistics. Vol. I Theory, Method and History. London and New York: Routledge, pp. 71-93.

Fludernik M (1993) The Fictions of Language and the Languages of Fiction. London: Routledge.

Fludernik M (2017) The many in action and thought: Towards a poetics of the collective in narrative. Narrative 25(2): 139-163. 
The Years Work in Stylistics 2017 Jane Lugea, Queen's University Belfast, UK

Fowler R (1966/2017) Essays on Style and Language: Linguistic and Critical Approaches to Literary Style. Routledge Revivals series. London and New York: Routledge.

Freeman M (2017a) Multimodalities of metaphor: A perspective from the poetic arts. Special Issue: Bidirectionality and Metaphor. Poetics Today 31(1):61-92.

Freeman M (2017b) Toward a theory of poetic iconicity: The ontology of semblance. In Zirker A, Bauer M, Fischer $\mathrm{O}$ and Ljungberg C (eds) Dimensions of Iconicity. Amsterdam and Philadelphia: John Benjamins, pp. 99-117.

Friel B (1981) Translations. London: Faber.

Gavins J (2012/2017) Leda and the Stylisticians. In Burke M (ed) Stylistics. Vol. I Theory, Method and History. London and New York: Routledge, pp. 241-60.

Genette G (1972) [1980] Narrative Discourse. J. Lewin (trans.) Oxford: Basil Blackwell.

Gibbons A (2017) Reading $S$. across media: Transmedia storyworlds, multimodal fiction, and real readers. Narrative 25(3): 321-341.

Gibbons A and Whiteley S (2017) Contemporary Stylistics: Language, Cognition, Interpretation. Edinburgh: Edinburgh University Press.

Goodblatt C and Glickson J (eds) (2017a) Special Issue: Bidirectionality and Metaphor. Poetics Today 31(1):1-211.

Goodblatt C and Glickson J (2017b) Introduction: Bidirectionality and Metaphor. Special Issue: Bidirectionality and Metaphor. Poetico Today 31(1):1-14.

Gregoriou C (2017) Crime Fiction Migration: Crossing Languages, Cultures and Media. London and New York: Bloomsbury.

Gries ST (2017) Corpus approaches. In Dancygier B (ed) The Cambridge Handbook of Cognitive Linguistics. Cambridge: Cambridge University Press, pp. 590-606.

Groarke L (2017) Editorial cartoons and ART: Arguing with Pinocchio. In: Tseronis A and Forceville C (eds) Multimodal Argumentation and Rhetoric in Media Genres. Amsterdam and Philadelphia: John Benjamins, pp. 81-110.

Gómez-Jiménez EM (2017) nearerandnearerandNEARER: Foregrounding effects of the unconventional capitalization in the experimental poetry of E. E. Cummings. Journal of Literary Semantico 46(2): 109-129.

Graham SL and Hardaker C (2017) (Im)politeness in digital communication. In Culpeper J, Haugh M and Kådår D (eds) The Palgrave Handbook of 
The Years Work in Stylistics 2017 Jane Lugea, Queen's University Belfast, UK Linguistic (Im) politeness. Houndmills, Basingstoke: Palgrave Macmillan, pp. 785-814.

Gunn D (2017) Reading Strether: Authorial narration and free indirect discourse in The Ambassadors. Narrative 25(1): 28-44.

Hakemulder F and van Peer W (2016) Empirical stylistics. In Sotirova V (ed) The Bloomsbury Companion to Stylistics. London: Bloomsbury, pp. 380399.

Hakemulder F and Kuijpers MM, Tan ES, Bålint K and Doicaru MM (eds) (2017) Narrative Absorption. Amsterdam and Philadelphia: John Benjamins.

Hall G (2012/2017) Revenons à nos mouton! Metaphor and idiom in EFL and ESL teaching and learning. In Burke M (ed) Stylistics. Vol. III The Practical Value of Stylistic Analysis. London and New York: Routledge, pp. 94-105.

Halliday MAK (1971/2017) Linguistic function and literary style. In Burke M (ed) Stylistics. Vol. I Theory, Method and History. London and New York: Routledge, pp. 39-70.

Hamilton C (2017) Stylistics as rhetoric. In Burke M (ed) Stylistics. Vol. I Theory, Method and History. London and New York: Routledge, pp. 339. 53.

Harrison C (2017a) Finding Elizabeth: Construing memory in Elizabeth is Missing by Emma Healey. Journal of Literary Semantics 46(2): 131-151.

Harrison C (2017b) Cognitive Grammar in Contemporary Fiction. Amsterdam: John Benjamins.

Hatavara M, Hyvärinen M, Mildorf J (eds) (2017) Special Issue: Narrating Selves in Everyday Contexts. Style. 51(3).

Hoffman CR (2017) Narrative perspectives on voice in fiction. In Locher M and Jucker A (eds) (2017) Pragmatics of Fiction. Berlin and Boston: De Gruyter, pp. 159-95.

Hoffmann T (2017) Construction grammars. In Dancygier B (ed) The Cambrigge Handbook of Cognitive Linguistics. Cambridge: Cambridge University Press, pp. 310-29.

Holtgraves T and Bonnefon JF (2017) Experimental approaches to linguistic (im)politeness. In Culpeper J, Haugh M and Kådår D (eds) The Palgrave Handbook of Linguistic (Im) politeness. Houndmills, Basingstoke: Palgrave Macmillan, pp. 381-401.

Ikeo R (2007/2017) Unambiguous free indirect discourse? A comparison between 'straightforward' free indirect speech and thought presentation and cases ambiguous with narration. In Burke M (ed) Stylistics. Vol. II 
The Years Work in Stylistics 2017 Jane Lugea, Queen's University Belfast, UK

Pragmatics, Discourse and Narrative. London and New York: Routledge, pp. 187-208.

Jacobs AM (2015) Towards a neurocognitive poetics model of literary reading. In R Willems (ed) Towards a Cognitive Neuroscience of Natural Language Use. Cambridge: Cambridge University Press, pp. 135-159.

Jacobs AM and Lüdtke J (2017) Immersion into narrative and poetic worlds: A neurocognitive poetics perspective. In Hakemulder $\mathrm{F}$ and Kuijpers MM, Tan ES, Bålint K and Doicaru MM (eds) Narrative Absorption. Amsterdam and Philadelphia: John Benjamins, pp. 69-96.

Janda LA (2017) The quantitative turn. In Dancygier B (ed) The Cambridge Handbook of Cognitive Linguistics. Cambridge: Cambridge University Press, pp. 498-514.

Jeffries L and Walker B (2017) Keywords in the Press: The New Labour Years. Research in Cor Discourse series. London and New York: Bloomsbury.

Jenkins H (2006) Convergence Culture: Where Old and New Media Collide. New York: New York University Press.

Jucker AH and Staley L (2017) (Im)politeness and developments in methodology. In Culpeper J, Haugh M and Kådår D (eds) The Palgrave Handbook of Linguistic (Im) politeness. Houndmills, Basingstoke: Palgrave Macmillan, pp. 119-41.

Kasher A (ed) (1988) Pragmatics. Critical Concepts in Linguistics series. London and New York: Routledge.

Kessler F (2017) "Spellbound in darkness": Narrative absorption discussed by film theory. In Hakemulder F and Kuijpers MM, Tan ES, Bålint K and Doicaru MM (eds) Narrative Absorption. Amsterdam and Philadelphia: John Benjamins, pp. 119-132.

Kjelsen JE (2017) The rhetorical and argumentative potentials of press photography. In: Tseronis A and Forceville C (eds) Multimodal Argumentation and Rhetoric in Media Genres. Amsterdam and Philadelphia: John Benjamins, pp. 51-79.

Kizelbach U (2017) Impoliteness in fiction. In Locher M and Jucker A (eds) (2017) Pragmatics of Fiction. Berlin and Boston: De Gruyter, pp. 425-53.

Kress G and van Leeuwen TJ (2006) Reading Images: The Grammar of Visual Design. London and New York: Routledge. 2 edition.

Kuhn M and Thon JN (2017) Guest editors' column: Transmedial narratology: current approaches. Narrative 25(3): 253-255.

Kuijperts MM, Hakemulder F, Bålint K, Doicaru M and Tan E (2017) Towards a new understanding of absorbing reading experiences. In Hakemulder F and Kuijpers MM, Tan ES, Bålint K and Doicaru MM 
The Years Work in Stylistics 2017 Jane Lugea, Queen's University Belfast, UK

(eds) Narrative Absorption. Amsterdam and Philadelphia: John Benjamins, pp. 29-47.

Lakoff G and Johnson M (1980) Metaphors We Live By. Chicago: University of Chicago Press.

Langacker R (1987) Foundations of Cognitive Grammar, Vol. I: Theoretical Prerequisites. Stanford, CA: Stanford University Press.

Langacker R (1991) Foundations of Cognitive Grammar, Vol. II: Descriptive Application. Stanford, CA: Stanford University Press.

Langacker R (2017) Cognitive grammar. In Dancygier B (ed) The Cambridge Handbook of Cognitive Linguistics. Cambridge: Cambridge University Press, pp. 262-83.

Littlemore J (2017) Metonymy. In Dancygier B (ed) The Cambridge Handbook of Cognitive Linguistics. Cambridge: Cambridge University Press, pp. 40722.

Leech G (1966/2017) Linguistics and the figures of rhetoric. In: R. Fowler (ed) Essays on Style and Language: Linguistic and Critical Approaches to Literary Style. Routledge Revivals series. London: Routledge, pp. 165-156.

Locher M and Jucker A (eds) (2017) Pragmatics of Fiction. Berlin and Boston: De Gruyter.

Lou A (2017) Multimodal simile: The 'when' meme in social media. English Text Construction. 10(1): 106-131.

Mahlberg M (2007) A corpus stylistic perspective on Dicken's Great Expectations. In Lambrou M and Stockwell P (eds) Contemporary Stylistics. London: Continuum, pp19-31.

Mahlberg M and McIntyre D (2011) A case for corpus stylistics: Ian Fleming's Casino Royale. English Text Construction. 4(2): 204-27.

Mastropierro L (2017) Corpus Stylistics in Heart of Darkness and its Italian Translations. Research in Corpus and Discourse series. London and New York: Bloomsbury.

Mastropierro L and Mahlberg M (2017) Key words and translated cohesion in Lovecraft's Mountains of Madness and one of its Italian translations. English Text Construction 10(1): 78

McIntyre D (2012/2017) Corpus stylistics in the classroom. In Burke M (ed) Stylistics. Vol. III The Practical Value of Stylistic Analysis. London and New York: Routledge, pp. 165-86.

McIntyre D (2004/2017) Point of view in drama. In Burke M (ed) Stylistics. Vol. II Pragmatics, Discourse and Narrative. London and New York: Routledge, pp. 39-70. 
The Years Work in Stylistics 2017 Jane Lugea, Queen's University Belfast, UK

McIntyre D and Bousfield D (2017) (Im)politeness in fictional texts. In Culpeper J, Haugh M and Kádár D (eds) The Palgrave Handbook of Linguistic (Im) politeness. Houndmills, Basingstoke: Palgrave Macmillan, pp. 759-83.

McIntyre D and Jeffries L (2017) Teaching stylistics: Foregrounding in E.E. Cummings. In Knight B (ed) Teaching Literature: Text and Dialogue in the English Classroom. Houndmills, Basingstoke: Palgrave Macmillan, pp. 15572 .

Meyer M (2017) What is Rhetoric? Oxford: Oxford University Press.

Murphy TP and Walsh KS (2017) Unreliable third person narration? The case of Katherine Mansfield. Journal of Literary Semantico 46(1):67-85.

Oakley T and Pascual E (2017) Conceptual blending theory. In Dancygier B (ed) The Cambridge Handbook of Cognitive Linguistics. Cambridge: Cambridge University Press, pp. 423-48.

Panagiotidou ME (2017) Ekphrasis, cognition and iconicity: An analysis of W.D. Snodgrass's “Van Gogh: 'The Starry Night'”. In Zirker A, Bauer M, Fischer $\mathrm{O}$ and Ljungberg $\mathrm{C}$ (eds) Dimensions of Iconicity. Amsterdam and Philadelphia: John Benjamins, pp. 135-50.

Page R (ed) (2010) New Perspectives on Narrative and Multimodality. New York: Routledge.

Page R (2017) Narratives Online: Shared Stories in Social Media. Cambridge: Cambridge University Press.

Pascal R (1977) The Dual Voice. Manchester: Manchester University Press.

Philpot DK (2017) Character Focalization in Children's Novels. Houndmills, Basingstoke: Palgrave Macmillan.

Riddle Harding J (2017) Similes, Puns and Counterfactuals in Literary Narrative. London and New York: Routledge.

Rundquist E (2017) Free Indirect Style in Modernism: Representations of Consciousness. Amsterdam and Philadelphia: John Benjamins.

Schubert C (2017) Constructing the antihero: Linguistic characterisation in current American television series. Journal of Literary Semantics 46(1):25-46.

Scott J (2012/2017) Creative writing: A stylistics approach. In Burke M (ed) Stylistics. Vol. III The Practical Value of Stylistic Analysis. London and New York: Routledge, pp. 292-306.

Semino E (1995/2017) Schema theory and the analysis of text worlds in poetry. In Burke M (ed) Stylistics. Vol. IV The Multidisciplinarity of Stylistics. London and New York: Routledge, pp. 65-95. 
The Years Work in Stylistics 2017 Jane Lugea, Queen's University Belfast, UK

Shamina EA (2017) Iconicity in English literary neologisms. In Zirker A, Bauer M, Fischer O and Ljungberg C (eds) Dimensions of Iconicity. Amsterdam and Philadelphia: John Benjamins, pp. 85-96.

Shen D (2017) Joint functioning of two parallel trajectories of signification in Ambrose Bierce's 'A Horseman in the Sky' Style 51(2): 125-143.

Shen D (2005/2017) How stylisticians draw on narratology: Approaches, advantages and disadvantages. In Burke M (ed) Stylistics. Vol. II Pragmatics, Discourse and Narrative. London and New York: Routledge, pp. 51-65.

Short M (1999/2017) Graphological deviation, style variation and point of view in Marabou Stork Nightmares by Irvine Welsh. In Burke M (ed) Stylistics. Vol. II Pragmatics, Discourse and Narrative. London and New York: Routledge, pp. 240-55.

Simpson P (2010/2017) Point of view. In Burke M (ed) Stylistics. Vol. II Pragmatics, Discourse and Narrative. London and New York: Routledge, pp. 97-114.

Simpson P (2014) Stylistics: A Resource Book for Students. London and New York: Routledge. $2^{\text {nd }}$ edition.

Sinclair J (1966/2017) Taking a poem to pieces. In: Fowler R (ed) Evsays on Style and Language: Linguistic and Critical Approaches to Literary Style.

Routledge Revivals series. London: Routledge, pp. 68-81.

Sinclair J (1966) Beginning the study of lexis. In Bazell CE, Catford JC, Halliday MAK, and Robins RH (eds) In Memory of J. R. Firth. London: Longman, p. 410-430.

Sotirova V (2013) Consciousness in Modernist Fiction: A Stylistic Study. Houndsmills: Palgrave Macmillan.

Sotirova V (ed) (2015) The Bloomsbury Companion to Stylistics. London: Bloomsbury.

Spencer-Oatey H and Žegarac V (2017) Power, solidarity and (im)politeness. In Culpeper J, Haugh M and Kådår D (eds) The Palgrave Handbook of Linguistic (Im) politeness. Houndmills, Basingstoke: Palgrave Macmillan, pp. 119-41.

Stockwell P (2012/2017) The reader's paradox. In Burke M (ed) Stylistico. Vol. III The Practical Value of Stylistic Analysis. London and New York: Routledge, pp. 200-210.

Stockwell P and Whiteley S (eds) (2014) The Cambridge Handbook of Stylistics. Cambridge: Cambridge University Press. 
The Years Work in Stylistics 2017 Jane Lugea, Queen's University Belfast, UK

Sullivan K (2017) Conceptual metaphor. In Dancygier B (ed) The Cambridge Handbook of Cognitive Linguistics. Cambridge: Cambridge University Press, pp. 383-406.

Sweetser E (2017) Opening commentary: Conceptual mappings. In Dancygier B (ed) The Cambridge Handbook of Cognitive Linguistics. Cambridge: Cambridge University Press, pp. 379-84.

Tan E, Doicaru MM, Hakemulder F, Balint K and Kuijpers MM (2017) Into film: Does absorption in a movie's story world pose a paradox?. In Hakemulder F and Kuijpers MM, Tan ES, Bálint K and Doicaru MM (eds) Narrative Absorption. Amsterdam and Philadelphia: John Benjamins, pp. 69-96.

Toolan M (ed) (2002) Critical Discourse Analysis. Critical Concepts in Linguistics series. London and New York: Routledge.

Toolan M (1990/2017) Stylistics and its discontents: Or, getting off the Fish "hook". In Burke M (ed) Stylistics. Vol. I Theory, Method and History. London and New York: Routledge, pp. 94-112.

Troscianko ET (2017) Feedback in reading and disordered eating. In Burke M and Troscianko ET (eds) Cognitive Literary Science: Dialogues between Literature and Cognition. Oxford: Oxford University Press, pp. 169-94.

Tseronis A and Forceville C (2017) Multimodal Argumentation and Rhetoric in Media Genres. Amsterdam and Philadelphia: John Benjamins.

Van den Hoven P and Schilperoord J (2017) Perspective by incongruity: Visual argumentative meaning in editorial cartoons. In: Tseronis A and Forceville C (eds) Multimodal Argumentation and Rhetoric in Media Genres. Amsterdam and Philadelphia: John Benjamins, pp. 137-163.

Van den Hoven P and Yang Y (2013) The argumentative reconstruction of multimodal discourse: Taking the ABC coverage of president Hu Jintao's visit to the USA as an example. Argumentation 27: 403-424.

Vandelanotte L (2017) Viewpoint. In Dancygier B (ed) The Cambridge Handbook of Cognitive Linguistics. Cambridge: Cambridge University Press, pp. 157-71.

Verdonk P (2013/2017) The language of poetry: The application of literary stylistic theory in university teaching. In Burke M (ed) Stylistics. Vol. III The Practical Value of Stylistic Analysis. London and New York: Routledge, pp. 307-327.

Verdonk P (1999/2017) The liberation of the icon: A brief survey from classical rhetoric to cognitive stylistics. In Burke M (ed) Stylistics. Vol. I Theory, Method and History. London and New York: Routledge, pp. 393404 . 
Verdonk P (2006/2017) Style. In Burke M (ed) Stylistics. Vol. I Theory, Method and History. London and New York: Routledge, pp. 280-304.

Vogel A (2017) How to build a metaphor: Novel metaphors construed by concrete elements in Tomas Tranströmer's poetry. Style 51(4): 506-525.

Wales K (2014/2017) The stylistic toolkit: Methods and sub-disciplines. In Burke M (ed) Stylistics. Vol. I Theory, Method and History. London and New York: Routledge, pp. 226-40.

Werth P (1994/2017) Extended metaphor: A Text-World Account. In Burke M (ed) Stylistics. Vol. IV The Multidisciplinarity of stylistics. London and New York: Routledge, pp. 1-26.

Werth P (1999) Text Worlds: Representing Conceptual Space in Discourse. Harlow: Longman.

Wildfeuer J and Pollaroli C (2017) Seeing the untold: Multimodal argumentation in movie trailers. In: Tseronis A and Forceville $\mathrm{C}$ (eds) Multimodal Argumentation and Rhetoric in Media Genres. Amsterdam and Philadelphia: John Benjamins, pp. 189-215.

XU Yun S (2017) Translation of Autobiography: Narrating Self, Translating the Other. Amsterdam and Philadelphia: John Benjamins.

Zerkowitz J (2012/2017) Stylistics for language teachers. In Burke M (ed) Stylistics. Vol. III The Practical Value of Stylistic Analysis. London and New York: Routledge, pp. 266-280.

Zirker A (2017) Performative iconicity: Chiasmus and parallelism in William Shakespeare's 'The Rape of Lucrece'. In Zirker A, Bauer M, Fischer O and Ljungberg C (eds) Dimensions of Iconicity. Amsterdam and Philadelphia: John Benjamins, pp. 85-96.

Zirker A, Bauer M, Fischer O and Ljungberg C (eds) (2017) Dimensions of Iconicity. Amsterdam and Philadelphia: John Benjamins.

Zyngier S and Fialho O (2010/2017) Pedagogical stylistics, literary awareness and empowerment: A critical perspective. In Burke M (ed) Stylistics. Vol. III The Practical Value of Stylistic Analysis. London and New York: Routledge, pp. 71-93. 